\section{構造計算書審査技術に関する研 究}

一概略審查手法と詳細審查手法による 審査の効率化一

北本拓也 一 $* 1 \quad$ 藤井大地一 $* 2$

キーワード :

改正建築基準法, 作業量の分析, 審査の効率化

Keywords:

A revised building law, An estimation of work load, Effective working

\section{A STUDY ON STRUCTURE CHECKS EXAMINATION TECHNOLOGY}

- Effective working by outline examination and detailed examination -

\section{Takuya KITAMOTO - * 1 \\ Daiji FUJII — $* 2$}

The revised building standard law established in 2007 confused building confirmation application process in building work places. This cause of the confusion is related to the strict examination duty ruled by the revised law. In this paper, the contents of the strict examination were analyzed, the work rate was measured, and the working time was measured. Furthermore two techniques to make the examination process more efficient were proposed. One is an effective technique in strict examination, and another is an outline examination. In the outline examination the work rate is small, however a building confirmation application can't be judged exactly. In contrast, in strict examination work rate is heavy, however a building confirmation application can be judged more exactly. Both examination methods have different concept, however using both methods in coordination can make the examination process more effectively. In the previous paper, the strict examination process was shown, and in this paper outline one is mainly discussed.

\section{1 序論}

\section{$1-1$ 研究の背景}

本研究では，構造計算書の審査技術の向上を目的とし，構造計算 書の審査を効率化する手法の開発を行っている. 前報告 ${ }^{1)}$ では, 構 造計算書の審査に必要となる事項を体系化し，その体系化に基づい て作成した審査支援ツール ( R C 造) を提示した。 また，この審査支 援ツールは, 2007 年 6 月施行の改正建築基準法（以下, 「改正法」 という）による厳格化審查注1)に対応したものであることを示した。

ところで, この厳格化審查は, 設計者が作成した構造計算書の計 算過程を，設計とほぼ同じプロセスで 1 ステップずつ審査していく もので, 審査に相当な作業量を要する. 改正法は, 2005 年 11 月に 発覚した耐震強度偽装事件の教訓から, 偽装設計・不適切設計を確 認申請の審査の中で検出することを目的としたものであったが，設 計する側にも審査する側にも大きな混乱が生じた．この混乱の一因 として, 改正法が規定した厳格化審査は, 相当な作業量を要するも のであったことがその背景にあったのではないかと考えられる。こ うしたことから，審査日数の短縮や審査作業の効率化は今日的な課 題である.

\section{$1-2$ 研究の目的}

本報告では, 改正法が規定した峳格化審查の作業量を示寸副次的 な資料とするために，作業内容を分析し，部分的にではあるが作業 量と作業時間を試算する.

一方, 構造計算書の審查方法は, 改正法が要求している審査方法 の他に，審査対象の建物規模であれば標準的にこの程度の大きさの 部材が必要とされるという資料を用意し, 設計されている部材断面 と比較することで明らかに耐震要素の貧弱な設計を検出するという 方法も考えられる.ここでは, 前者の審查方法を「詳細審査」, 後者 の審査方法を「概略審査」と呼ぶことにする. 詳細審査は, より確 実に不適切設計を検出することができるが，膨大な作業時間を要す
るという短所を持っている。一方，概略審査は，より短い時間で耐 震要素の貧弱な設計を検出できるが，標準的な設計よりも貧弱であ るからと言って不適切な設計であるとは断定できないという短所を 持っている。これらの関係を図 1 に示す。これらの長所・短所を踏 まえて，概略審査で疑問ありと判断された設計やその建物の疑問あ りとされる部位を重点的に詳細審査でチェック寸るという手法で審 查の効率化を図る方法が考えられる.

そこで，本報告では，概略審查を支援するツール ( R C 造)を提示 し，また，前報告で示した詳細審査の支援ツールに改良を加え，こ の二つの支援ツールにより審查作業を効率化する手法を示す.

\section{2 改正法が規定した厳格化審査の審査作業 \\ 2-1 審査作業内容と作業量の分析}

改正法では審查内容を告示で規定し義務付け注 1)ている. 改正法 が義務付けた審査内容は, 「建築士免許の写しが添付されていること (の審査)」といった添付書類の審査を含め，構造設計のどの過程に おいて偽装・不適切設計が行われていたとしても検出できるよう各 段階における審査事項を定めている。改正法が規定する厳格化審査 の内容を模式図で示すと図 2 のようになると考えられる.これは, 前報告の表 1 を模式図として示したものである.

\begin{tabular}{|c|c|c|}
\hline & $\begin{array}{l}\text { 櫭 略 審 査 } \\
\text { ○改正法が規定する審査レベルを } \\
\text { 満たしていない }\end{array}$ & $\begin{array}{l}\text { 濓 細 審査 } \\
\text { 改正法が規定する綮格化審査に } \\
\text { 沿ったもの }\end{array}$ \\
\hline $\begin{array}{l}\text { 長 } \\
\text { 所 } \\
==- \\
\text { 短 } \\
\text { 所 }\end{array}$ & 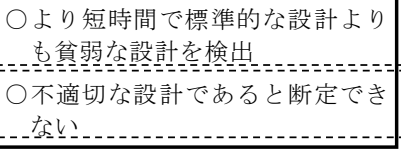 & 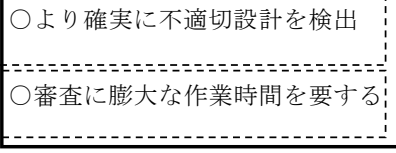 \\
\hline \multicolumn{2}{|c|}{$\begin{array}{l}\text { 概略審査で, } \\
\text { 短時間で審査し，ほぼ妥当な設 } \\
\text { 計であるかどうかを検出. }\end{array}$} & $\begin{array}{l}\text { 概略審査で, 疑問ありとされたも } \\
\text { のや, 疑問ありとされた構造部位 } \\
\text { を重点的に, 詳細審査で番査. }\end{array}$ \\
\hline
\end{tabular}

図 1 概略審査と詳細審査

本稿は日本建築学会中国支部研究発表会（2009.3）（2010.3）において発表. 広島県 工修

（７30-8511 広島市中区基町 10-52 広島県総務局営䋨課内）

2 近畿大学工学部 教授・博士 (工学)

Hiroshima Prefecture Office, M. Eng.

Prof., Faculty of Engineering, Kinki Univ., Dr. Eng. 


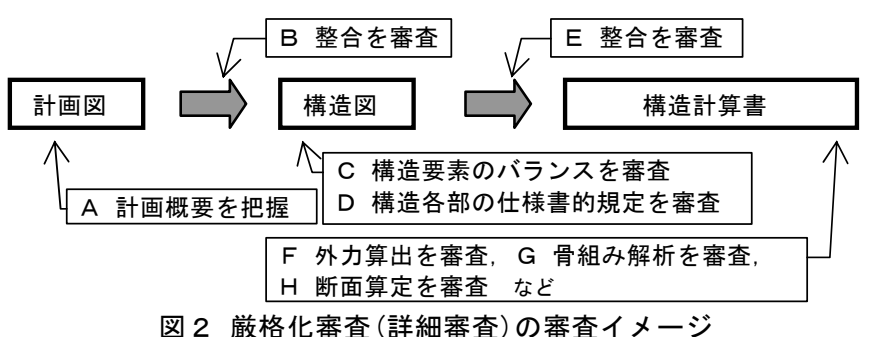

次に, 図 2 に示した審査の作業内容を分析する.

図 2 のからHの各段階において実施する審查作業を表 1 に示 す. また, 表 1 では, 審查事項の一部 $(\mathrm{C}$ と D ) についてその具体的 作業内容も例示している. 表 1 は作業内容の一部だが, 審査に必要 な事項をすべて書き出すと A 4 判 15 ページになる注2).

次に, この審査に必要な作業量を定量的に示寸ことを試みる. 本 報告では, 改正法が規定する審査の全体の作業量を示すことはでき なかったが, Hの「断面算定を審査」についてのみ, その審査作業 量を試算する.

作業量を試算する方法は, その審査に当たって必要となる数值の 読取り回数, 数式の選定回数, 数式に数值を入れて計算する回数, 結果を判断する回数など, 作業に必要な工程数を示す方法とする. この必要工程数は, 審查担当者が図表を用いながら手計算で構造計 算書の断面算定を審查し，同時に最低鉄筋量などの仕様書的規定の 審査も行うことを想定している.

まず, 4 辺固定スラブの審査に必要な作業量を分析する．作業量 算出の前提となる条件と作業内容の概要を表 2 に示す。さらに,
表 3 に必要な作業工程を示す．これに基づいて必要な作業工程を数 えた結果を表 4 のスラブ欄に示す.

同じことを小梁, 梁, 柱について行う. 紙面の都合上, 小梁, 梁, 柱 の前提条件と作業概要・作業工程は省略し, 作業工程数のみを表 4 に示す．表 4 により，スラブ 1 枚の審査に必要な作業工程数は 58 , 小梁 1 本は 83 , 梁 1 本は 146 , 柱 1 本は 173 であることがわかった.

\section{2-2 作業時間の試算}

次に，審査作業に要する時間を算出することを試みる．作業時間 の試算は，それぞれの作業工程に何秒の時間を要するかを想定して 積算する，表 4 の作業工程のうち「計算」は，電卓で計算すること を想定するため, [ 1 つの数值の入力], [途中数值を紙に転記する作 業], [計算結果を読取って紙に記載する作業]の 3 つに分解するもの とする.この考え方に基づき表 4 を書き直すと, 表 5 のようになる. この作業工程数のそれぞれに 1 回の作業時間を乗じて積算した結果 が同表の合計作業時間である。この結果， 1 枚のスラブの断面算定 の審査 (仕様書的規定の審査を含む. 以下同じ) に約 8 分，小梁 1 本 に約 13 分, 梁 1 本に約 23 分, 柱 1 本に約 27 分の時間を要すること が試算できた。

\section{3 概略審査による審査の効率化 3-1 概略審査手法の概要}

審查対象建築物の規模等を勘案して, 標準的に必要と考えられる 部材断面寸法と設計された部材断面寸法を比較する審査手法は，明 らかに構造要素が貧弱なものを検出するための簡易な手法である. この審査手法において必要とされるものが,「標準的に必要と考えら

\section{表 1 厳格化審査の審査内容}

\begin{tabular}{|c|}
\hline 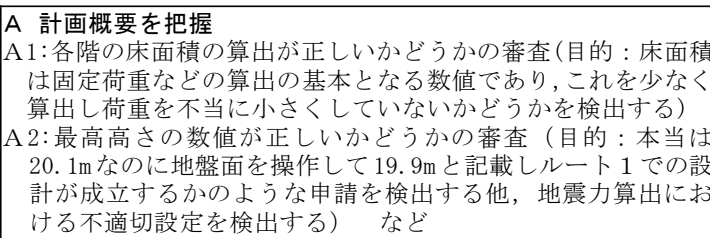 \\
\hline $\begin{array}{l}\mathrm{B} \text { 計画図から構造図への整合を審査 } \\
\mathrm{B} 1 \text { : 計画図上の柱梁壁の配置のと構造図で図面化されて } \\
\text { るかの審査 } \\
\text { B 2:スパン割, 階高が正しく構造図で図面化されているかの審査 } \\
\quad \text { (計画図の通り芯から躯体芯のずれの整合性審査を含む) } \\
\text { B 3:計画図で示されている寸法で, 構造図の躯体寸法が確保でき } \\
\text { ることの審査 など }\end{array}$ \\
\hline $\begin{array}{l}\text { C 構造要素のバランスを審査 } \\
\text { 片持ち梁の根元の部分が十分な構造体に取り付けられている } \\
\text { かどうかといった構造体として整合しない設計を検出する. }\end{array}$ \\
\hline $\begin{array}{l}\mathrm{D} \text { 構造各部の仕様書的規定を審査 } \\
\text { 柱主筋の最低鉄筋量が適合していかどうかなどの審査 }\end{array}$ \\
\hline $\begin{array}{l}\text { E 構造図から構造計算書への整合を審査 } \\
\text { 躯体のスパン割が正しく構造計算に用いられているかど } \\
\text { や壁のスリットが正しく入力さされているがうかなどの審 }\end{array}$ \\
\hline
\end{tabular}

\section{$\mathrm{F}$ 外力算出を審査}

$\mathrm{F} 1$ : 積載荷重の算出を審査

F 2:仕上げ荷重，躯体荷重の算出を審査

F 3:地震荷重の算出を審査 など

\section{G 骨組み解析を審査}

$\mathrm{G} 1:$ 剛床仮定などのモデル化を審査

$\mathrm{G} 2$ : 計算ルートの適合を審査

$\mathrm{G} 3$ : 柱梁の断面 2 次モーメントの数值の審査 (柱梁接合部の剛域 長さの審査，壁剛性の審査を含む)

G4:解析結果である各部の作用モーメントなどの数值の審査

\section{$\mathrm{H}$ 断面算定を審查}

算出された作用モーメント, せん断力, 軸力に対して, その 柱梁などが許容応力度内に納まっていることなどの審査
○ベランダなどであまりにも出幅の長い(例えば $2 \mathrm{~m}$ 以)片持ちスラブはないかー[ない＝OK, ある＝注意 $]$ 片持ちスラブの根元は, そのモーメントを支えるだけの受け材(梁)があるか $\rightarrow$ ある $=\mathrm{OK}$, ない=注意 $]$ ○片持ちスラブでないスラブはその4周に連続して梁があるか 4周を梁で囲まれるスラブの面積が極端に大きい(例えば $30 \mathrm{~m}^{2}$ 以上)ものはないか 意]

屋上のペントハウスの外壁の下にそれを受ける梁があるか

重量のある設備機器の下にそれを受ける梁があるか

片持ち梁がある場合, その片持ち梁の根元はそのモーメントを受けるための柱又は梁が同一構面にある か

極端にスパンの長い(例えば10m以上)梁はないかい[ない＝OK，ある二注意 $]$

梁配筋は両端は上端が, 中央は下端が多く配置されているか(地盤反力を受ける基礎梁についてはその 逆,つまり, 両端は下端が, 中央は上端が多く配筋されているか $\rightarrow[\mathrm{YES}=\mathrm{OK}, \mathrm{NO}=$ 注意

小梁考受ける梁は, その小梁よりも梁丈が大きいか $\rightarrow[\mathrm{YES}=\mathrm{OK}, \mathrm{NO}=$ 注意 $]$

大きい面積のスラブ荷重を受ける梁ほど梁丈が大きくなっているか

柱は, 下の階ほど太く(または鉄筋量が多く), 広い面積の床を支えるものほど太く(または鉄筋量が多く)な っているか $\rightarrow[\mathrm{YES}=\mathrm{OK}, \mathrm{NO}=$ 注意 $]$

柱は, その頂部から基礎梁まで垂直につながっているか。つまり, 柱の下に柱がないものがあるかい[柱は 基礎までつながっている $=\mathrm{OK}$, つながっていないものがある＝注意 $]$

斜め柱はないか $[$ ない $=\mathrm{OK}$, ある＝注意 $]$

$\mathrm{XX}$ 方, Y方向以外の構面の梁はないか $\rightarrow$ ない $=\mathrm{OK}$, ある=注意 $]$

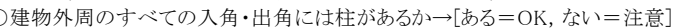

耐力壁は, X方向にもY方向にも配置されており，偏らずほぼ均等に配置されているか =注意]

耐力壁は下の階ほど多〈なっているか $\rightarrow[\mathrm{YES}=\mathrm{OK}, \mathrm{NO}=$ 注意 $]$

バランスの審査だけで不適切設計を特定できるわけではない. 上記で注意」になった場合は, そのバランス の悪さを構造計算によって解決していることを, G, Hでチェックする.

\section{<小梁, 梁 $>$}

梁の全スパンに渡り，上端にも下端にも主筋があるか $\rightarrow[\mathrm{YES}=0 \mathrm{~K}, \mathrm{~N} 0=\mathrm{NG}$ (法令上は例外あり) $]$ 両端の上端，中央部の下端の主筋の鉄筋量は， $0.4 \%$ 以上あるか $\rightarrow[\mathrm{YES}=0 \mathrm{~K}, \mathrm{~N} 0=\mathrm{E}$ 長期モーメントにつ いて必要とする鉄筋量を $4 / 3$ 倍にした鉄筋量があることの検討が必要 (法令外) ]

主筋は，異形鉄筋D 13 以上であるか $\rightarrow[\mathrm{YES}=\mathrm{OK}, \mathrm{NO}=\mathrm{NG}$ (法令外) $]$

あばら筋は，異形鉄筋D 10 以上であるか $\rightarrow[\mathrm{YES}=0 \mathrm{~K}, \mathrm{~N} 0=\mathrm{NG}$ (法令外) $]$

あばら筋の間隔は, 梁丈の半分以下かつ $250 \mathrm{~mm}$ 以下であるか $\rightarrow[\mathrm{YES}=0 \mathrm{~K}, \mathrm{~N} O=\mathrm{NG}$ (例外あり, 法令外) ] 注意 : 法令上の制限值は梁丈の $3 / 4$ 以下である

あばら筋比は，0.2\%以上であるか $[\mathrm{YES}=0 \mathrm{~K} ， \mathrm{~N} 0=\mathrm{NG}$ (法令外) $]$

梁の有効長さは，その梁の梁丈の 10 倍以内であるか $\rightarrow[\mathrm{YES}=0 \mathrm{~K}, \mathrm{~N} 0=$ たわみ検討が必要 $]$

備考：「NG(法令外)」とは，法令上は定めがないためこれを直接的に違法とする条文はないけれども， 学会規準等で排除されているもの

柱, スラブ, 耐力壁は, 紙面の都合上, 省略した。 
表 2 作業量算出の前提条件と作業概要

$<4$ 辺固定スラブの前提条件 $>$

スラブの構造図が示されており, 配筋が示され ている.

スラブの仕上げ重量と積載荷重の合計 $\left(\mathrm{N} / \mathrm{m}^{2}\right)$ の数值が示されている

<同，作業概要 $>$

スラブ厚さの最小值条件の適合を審査.

長辺方向・短辺方向の配筋間隔を審査.

スラブ厚さからスラブ自重を算出し，既值の積

載荷重などと合わせることでスラブの面積あ

たり荷重を算出し，スラブ各部に生じる曲げモ

一メントを算出

スラブ厚さ，かぶりなどから d を算出し，鉄筋

量とで許容曲げモーメントを算出.

これらで, 許容応力度以下であることを審査.

（許容応力度以下であることの審査箇所は，短 刀中央下，短辺端部上，長辺中央下，長辺端部 上の 4 箇所)

※紙面の都合上, 小梁・梁・柱は掲載を省略する.

\section{表 4 作業工程数}

\begin{tabular}{|c|r|r|r|r|}
\hline 作業内容 & スラブ & 小梁 & 梁 & 柱 \\
\hline 数値の読取 & 9 & 13 & 25 & 36 \\
\hline 文字の読取 & 1 & 2 & 2 & 2 \\
\hline 数値の選定 & 2 & 4 & 4 & 4 \\
\hline 数式の選定 & 6 & 18 & 9 & 11 \\
\hline グラフの読取 & 0 & 2 & 9 & 8 \\
\hline 計算 & 25 & 34 & 69 & 81 \\
\hline 判断 & 15 & 10 & 28 & 31 \\
\hline 合 計 & 58 & 83 & 146 & 173 \\
\hline
\end{tabular}

表 3 必要な作業工程 (スラブ)

\begin{tabular}{|c|c|c|}
\hline 作業 & 検証に必要な情報·作業の内容 & 作業の細分 \\
\hline 数値の読取 & スラブの短辺長さ (mm) & \\
\hline 数值の読取 & スラブの長辺長さ $(\mathrm{mm})$ & \\
\hline 数値の読取 & スラブの厚さ(mm) & \\
\hline 数値の読取 & スラブのかぶり厚さ $(\mathrm{mm})$ & \\
\hline 数値の読取 & 仕上げ荷重＋積載荷重 $\left(\mathrm{N} / \mathrm{m}^{2}\right)$ & \\
\hline 文字の読取 & 鉄筋の SD295, SD345 の別 & \\
\hline 数値の選定 & 使用鉄筋の許容応力度の選定 & \\
\hline 判断 & |最低スラブ厚さの適合判定 & 判断 \\
\hline \multirow{3}{*}{ 判断 } & スパン厚さ関係の適合判定 & 数式の選定 \\
\hline & 式:t/ $l_{x}$ & 計算 \\
\hline & 判定: $t / l_{x} \geqq 1 / 30$ & 判断 \\
\hline \multirow{4}{*}{ 判断 } & 変位制限の適合判定 & 数式の選定 \\
\hline & 式: $\lambda=l_{\mathrm{y}} / l_{\mathrm{x}}$ & \multirow[b]{2}{*}{ 計算 } \\
\hline & \begin{tabular}{|l} 
式: $t_{\min }=0.02 *((\lambda-0.7) /(\lambda$ \\
$-0.6)) *\left(1+w_{p} / 10000+l_{x} / 10000\right) * l_{x}$
\end{tabular} & \\
\hline & 判定: $t_{\min } \leqq \mathrm{t}$ & 判断 \\
\hline \multirow{2}{*}{ 算出 } & スラブ自重 $\left(\mathrm{N} / \mathrm{m}^{2}\right)$ の算出 & 数式の選定 \\
\hline & 式: $w=t * 24$ & 計算 \\
\hline \multirow{3}{*}{ 算出 } & 作用モーメントの算出 & 数式の選定 \\
\hline & 式: $w_{x}=l_{y}{ }^{4} /\left(l_{x}{ }^{4}+l_{y}{ }^{4}\right) w$ & \multirow{2}{*}{ 計算 } \\
\hline & 式: $M_{x 1}=1 / 12 * w_{x} * l_{x}{ }^{2}$ & \\
\hline 数値の読取 & 鉄筋径, ピツチ & \\
\hline 数値の選定 & 使用鉄筋の断面積の選定 & \\
\hline 判断 & 鉄筋ピツチの適合判定 & 判断 \\
\hline \multirow{3}{*}{ 判断 } & |最低鉄筋量の適合判定 & |数式の選定 \\
\hline & 式: $\mathrm{p}_{\mathrm{t}}=\mathrm{a} /(\mathrm{d} * @)$ & 計算 \\
\hline & 判定: $p_{t} \geqq 0.2 \%$ & 判断 \\
\hline \multirow{4}{*}{ 算出 } & 許容モーメントの算出 & 数式の選定 \\
\hline & 式: $d=t-a-d_{1} / 2$ & 計算 \\
\hline & 式: $j=7 / 8 * d$ & 計算 \\
\hline & 式:M=a $a_{t} * f * j$ & 計算 \\
\hline 算出 & 検定比の算出 & 計算 \\
\hline 判断 & 許容応力度内の判断 & 判断 \\
\hline
\end{tabular}

枠右側の数字は, その工程の回数
表 5 作業工程数と作業時間

\begin{tabular}{|c|c|c|c|c|c|}
\hline 作業内容 & スラブ & 小梁 & 梁 & 柱 & 1回の時間 \\
\hline 数值の読取 & 9 & 13 & 25 & 36 & (ア) 5 秒/回 \\
\hline 文字の読取 & 1 & 2 & 2 & 2 & (1) 5 秒/回 \\
\hline 数值の選定 & 2 & 4 & 4 & 4 & (ウ) 5 秒/回 \\
\hline 数式の選定 & 6 & 18 & 9 & 11 & (I) 5 秒/回 \\
\hline グラフの読取 & 0 & 2 & 9 & 8 & (才) 10 秒/回 \\
\hline \begin{tabular}{l|l} 
数値の入力 \\
\end{tabular} & 82 & 137 & 231 & 260 & (力) 3 秒/回 \\
\hline \multicolumn{6}{|l|}{ 途中数値の } \\
\hline \multicolumn{6}{|c|}{12 (キ) 3 秒/回 } \\
\hline \multicolumn{6}{|l|}{ 結果の読 } \\
\hline 取·記載 & 25 & 34 & 69 & 81 & (ク) 5 秒/回 \\
\hline 判断 & 15 & 10 & 28 & 31 & (ケ) 1 秒/回 \\
\hline
\end{tabular}

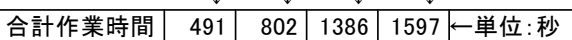
上記の (ア)から(ケ)の各工程における 1 回の作業時

間は, 次のように想定した。 上記の秒数は, 単に想 定しただけであり，特に裏づけはない。

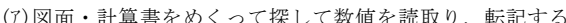
までの時間 (イ)図面・計算書をめくって探して文字を読取 り, 転記するまでの時間 (ウ)例えば, 鉄筋 D 10 の断面積で あれば, 鉄筋断面積表を探して，その表の中の断面積を読取 り転記するまでの時間 （エ）例えば，作用モーメントの算出 であれば, $\mathrm{M}_{\mathrm{x} 1}=1 / 12 *_{\mathrm{x}} * 1_{\mathrm{x}}{ }^{2}$ という式を探すのに必要な時間 (審 查担当者はその式の存在を知っているものとし，その式を再 確認する時間）（オ）グラフから対応する数值を読取り, 転記 するまでの時間 (力)数值を電卓に入力し, 入力した数值を 確認し，「十」「=」などのキー操作をするまでの時間 （キ)式の 計算と中において途中段階の数值を仮に書き留める時間 (ク)計算結果を読取って，数值を転記し，審査対象である構 造計算書の数值を探して照合するまでの時間（ケ）計算結果 から「OK」「NG」を判断する時間
れる部材断面寸法を導き出す技術」である，例えば，文献「構造設 計・部材断面事例集 ${ }^{2} 」$ は, 各種構造・規模のサンプル設計が掲載 されており，審査対象建築物の構造・規模に近いサンプル設計の断 面寸法を見ることで, 標準的な断面寸法を知ることができる.また, 熟練した構造技術者であれば, 詳細な設計や正規の構造計算の前段 で行う企画設計において, 柱・梁への作用応力を概算で算出し, 必 要断面を仮定することが実務上行われている.

本報告で提示する手法は，後者によるものである．すなわち，企 画設計段階において用いられる概算作用応力算出手法をシステム化 し，これによって算出された作用応力を支持することが可能な柱・ 梁部材断面のうち, 施工金額が最小となるもの(これを，「推奨部材 断面」と呼ぶ)を選出するものである(図 3 ).

\section{3-2 1 次設計における概算作用応力の算出}

躯体自重の正確な計上・累計や構造体をモデル化しての構造解析 をすることなく，構造図に記された表面的な情報のみを利用して， 求めようとする柱に作用する軸力や梁に作用する曲げモーメント值 (長期時，短期時)などを概算する手法を提示する.

図 4 は，1 次設計における作用応力を概算する手順を示したもの である. 図 4 に示寸手法は, 一般的に構造設計者が企画設計段階に おいて概算で構造部材を定める際に用いてきた手法であり, 文献「現 代建築学構造設計論 ${ }^{3)} 」 を$ 用いて具体化したものである.

\section{3-3 2 次設計における概算作用応力の算出}

次に, 2 次設計 (保有水平耐力設計) の必要保有水平耐力によって それぞれの柱・梁に作用する軸力や曲げモーメントを, $3-2$ ( 1 次 設計）と同様に概算する手法を示す，ただし，2 次設計においては， (1)審査しょうとする設計の柱・梁の性状によってD $\mathrm{s}$ 值が変化する ため, 建物全体に作用寸る水平力である必要保有水平耐力自体が
変化するものであること

(2) 1 次設計では剛性の違いによって応力が配分されるのに対して, 2 次設計では部材が持つ耐力の違いによって配分されるものであ り，梁の曲げ耐力はスラブ筋が引張り力に貢献するため一般に上 筋が引張りになる曲げ耐力の方が，下筋が引張りになる曲げ耐力 よりも大きくなることの考慮が必要であること

など，1 次設計との若干の差異を考慮する必要がある.

図 5 は，2 次設計における作用応力を概算する手順を示したもの である.

\section{3-4 耐力壁の水平力分担率の推定手法}

耐力壁付きラーメン構造の建築物の場合は, 耐力壁と柱梁ラーメ ンとがどれだけの割合で水平力を負担するかを推定する必要がある. これは，3-2 の図 4 のF-(1)と $3-3$ の図 5 のI-(1)で必要になる数 值でもある。ここでは，耐力壁の水平力分担率を推定するための考 え方を整理する.

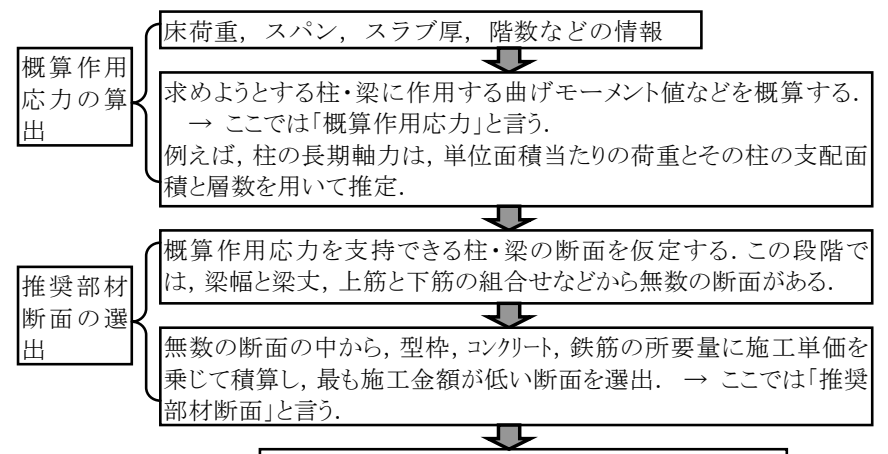

推奨部材断面と審査対象の設計の部材を比較

図 3 概略審查手法の概要 


\section{〈荷重データの算出〉}

A-11) スラブ厚さ, 柱梁寸法から自重を算出

A-(2) スラブの仕上げ荷重・積載荷重を手入力

A-(3) 壁・バルコニーなど付帯荷重を手入力

〈梁の長期曲げモーメント等の算出〉

B-(1) Aを用いて梁長さ・小梁位置などから梁の $\mathrm{CM}_{0} \mathrm{Q}_{0}$ を算出

B-(2) 端梁では, 外端の曲げモーメントを $0.6 \mathrm{C}$, 内端の曲げモ

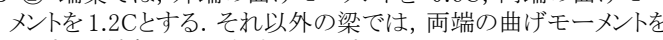
Cとする. 端部のせん断力は $Q_{0}$ とする.

〈柱の長期軸力の算出〉

C-(1) A を用いてスパン割から柱に軸力として作用する範囲内の 床・小梁・梁・柱の荷重を積算し, 1階分の荷重を算出

C-(2) C-(1)を用いて求めようとする柱よりも上の階の層数を乗じて 柱軸力を算出

〈柱の長期曲げモーメント等の算出〉

D-(1) B-(2)の梁端曲げモーメン卜(内柱の場合は左右の梁の差)を 上階柱の柱脚と下階柱の柱頭に配分する。

D-(2) 1階であれば D-(1)の半分を，それ以外であれば上を柱脚 曲げモーメントとする。

D-(3) D-(2)を用いて柱の長期せん断力とする

《建物全体の地震層せん断力を算出〉

-(1) A とスパン割から党あたり荷重を推測

E-(2) 各階床面積と E-(1)を用いて各階の自重を算出

E-(3) E-(2)を用いて Ai 分布を算出して地震層せん断力を算出 〈地震カによる柱の曲げモーメント等を算出〉

F-(1) E-(3)を水平力分担率により，柱分と耐力壁分に分割する. -(2) F-(1)の柱分をその階の柱本数により配分寸る.この時, 外 柱は内柱の 0.7 倍になるように配分しこれを柱のせん断力とす る.

-(3) F-(2)を用いて各階の反曲点高比に応じて柱頭・柱脚に曲 げモーメントを配分する.（反曲点高比: 1 階は 0.55 , 中間階は 0.5 , 最上階は 0.45 )

〈地震カによる梁の曲げモーメント等を算出〉

G-(1) F-(3)の柱頭曲げモーメントを用いてその上の階の柱脚曲け モーメントを E-(3)地震層せん断力分布により低減して求める.

G-(2) G-(1)とF-(3)を用いて梁端曲げモーメントを算出

G-(3) 端梁以外では他端の曲げモーメントを同じ值とするが, 端 梁ではG-(2)により求めた外端曲げモーメントを外柱・内柱の配 分を考慮して, 1/(0.7*2)を乗じて内端モーメントとする ${ }^{\text {注3) }}$

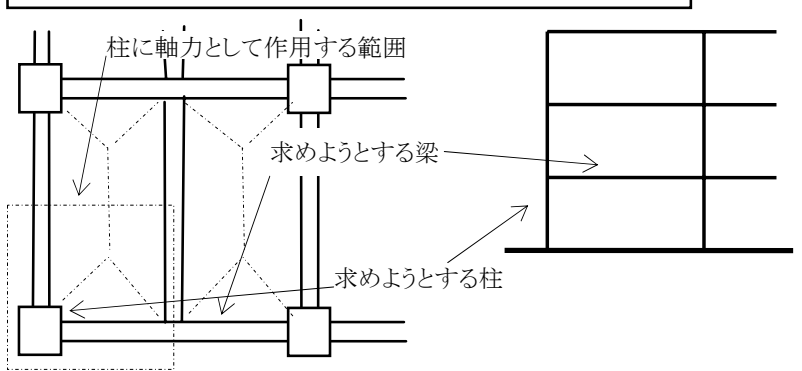

図 4 1 次設計における概算応力の算出

\section{1 次 設計}

1階における耐力壁の水平力分担率が $100 \%$ あるるとした場合の地震力

による転倒モーメントを算出〉

(1) 図4の E-(3)で各階の地震層せん断力を算出

(2) 上の階ほど水平力分担率が下がることを考慮する低減係数 $\alpha$ を用いて各階

の(1)を2階なら $(1-\alpha)$ 倍, 3階なら $(1-\alpha)^{2}$ 倍, n階なら $(1-\alpha)^{\mathrm{n}-1}$ 倍する.

(3) 各階の(2)を用いて上の階との差でもって耐力壁への作用力を算出

(4) 各階の (3)にその床のGLからの高さを乗じて合計することで地震力による耐 力壁の転倒モーメントを算出する.

長期荷重による柱下の支点反力を算出〉

5) 1 階柱の長期軸力を図-1のC-(2)で算出

6) 1 階床の影響範囲内の床荷重(自重+積載荷重)と梁・壁の自重を図-1の A(1)〜 (3)と同様に算出

(7) (5)+(6)で柱下の支点反力を算出

〈長期荷重等による耐力壁が転倒することに抵抗するモーメントの算出〉

(8) (7)に耐力壁両端の柱間距離を乗じて長期荷重による抵抗モーメントを算出

(9) 耐力壁に接している梁(境界梁, 地中梁を含む)の両端の短期許容曲げモ一 メントを算出

(10) (9)の両端の和をその梁の長さで除してその時のせん断力を算出

(11) (10のせん断力の各階の合計に耐力壁両端の柱間距離を乗じて梁せん断力 による抵抗モーメントを算出

12) (9)のうち耐力壁に接している側の梁の曲げモーメントの合計に(11)を加えたも のに影響係数 $\beta$ を乗じて境界梁による抵抗モーメントを算出(負の数になる)

(13) 8に(12)を加算して耐力壁の抵抗モーメントを算出

〈耐力壁の水平力分担率を算出〉

(14) (13)を(4)で除して耐力壁の水平力分担率を算出
《建物全体の必要保有水平耐力を算出

率から Ds 值を算出

その階の剛性率・偏心率から Fes 值を算出

(2) I-(1)の柱分をその階の柱本数により配分寸る.この時, 引抜側となる外柱は内柱の 0.6 倍, 圧縮側と 外柱は内柱の 0.8 倍になるように配分してこれを柱のせん断力とする.

階は 0.55 , 中間階は 0.5 , 最上階は 0.45$)$

必要保有水平耐カによる梁の曲げモーメント等を算出〉

により低減して求める.

(2) J-(1)と I-(3)を用いて梁端曲げモーメントを算出. ただし, 端梁以外では下引張りの曲げモーメントは 上引張りの曲げモーメントよりの 0.7 倍になるように配分する.

济算出

要保有水平耐力時の梁せん断力から作用する柱軸力の算定〉

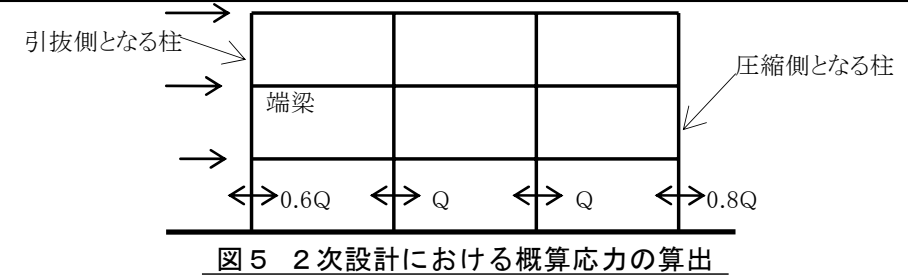

1 次設計における水平力は，弾性設計であるため，柱と耐力壁の 剛性によって配分されると考えられるが，実際には，耐力壁に水平 力が作用した場合に生じる脚部の引抜に抵抗可能な長期荷重を超え て抵抗することはない注5)。このため, 柱下部で引抜が生じないこ とを限度として耐力壁に作用する水平力を概算するものとした.

図 6 (左側) は, 1 次設計における耐力壁の水平力分担率を算出す る手順を示したものである。このうち，建築物全体に作用する地震 力は，図 4 で示した方法で概算が可能であり，長期荷重による反力 も同様の方法で概算した柱の長期軸力に 1 階の床荷重と基礎梁自重 を加えることで概算が可能である。また，境界梁の短期許容曲げモ 一メントは，第 4 章で作成した計算シートに梁の断面形状を入力す ることで算出できる。境界梁の曲げモーメントとせん断力によって

\section{2 次設 計}

く 1 階における耐力壁の水平力分担率が $100 \%$ あるとした場合の地震力による転倒 モーメントを算出〉

(1) 図5の $\mathrm{H}$-(3)で各階の必要保有水平耐力を算出

(2) 1次設計(2)と同じ処理をし, 同(3)と(4)の計算で而力壁の転倒モーメントを算出

〈長期荷重等による耐力壁が転倒することに抵抗するモーメントの算出〉

(3) 1 次設計(8)で算出した長期荷重による抵抗モーメントをそのまま用いる.

(4) 1 次設計(9)を梁端の全塑性モーメントに置き換えて算出

(5) 1 次設計(1011)と同じ処理をし, 梁せん断力による抵抗モーメントを算出

(6) (4)のうち耐力壁に接している側の梁の曲げモーメントの合計に(5)を加えたものに影響倸 数 $\beta$ を乗じて境界梁による抵抗モーメントを算出(負の数になる)

(7) (3)に(6)を加算して耐力壁の抵抗モーメントを算出

〈耐力壁の水平力分担率を算出〉

8) (7)を(2)で除して耐力壁の水平力分担率を算出

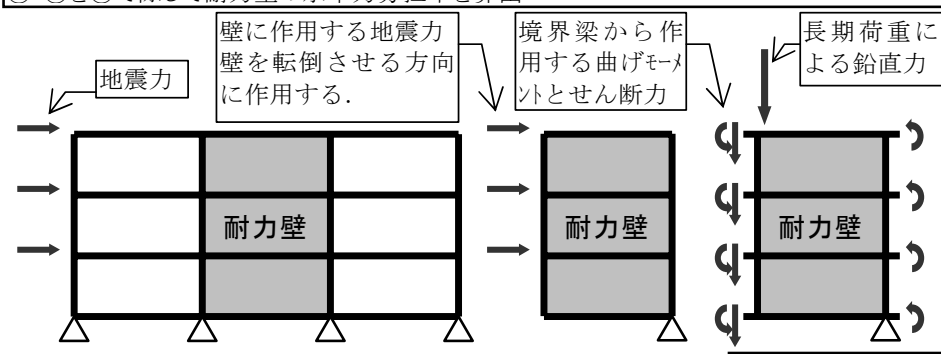

転倒に抵抗する力 
引抜を制止する効果に影響係数 $\beta$ を乗じているのは, 地震荷重作用 時に全ての梁が短期許容応力度ぎりぎりの状態になっているもので はないことを考慮するためである，また，上の階ほど水平力分担率 を低減する係数 $\alpha$ は, 連層耐力壁の場合, 上の階ほど壁の曲げ変形 による変位の影響が加わるため, 見かけ上の剛性が下がり, 水平力 分担率も下がることを考慮したものである注 6).

同じ考え方で，2次設計における耐力壁の水平力分担率も推定で

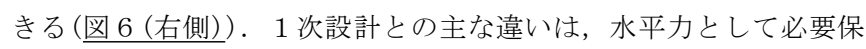
有水平耐力を用いることと, 境界梁で生じる曲げモーメントとして 全塑性モーメントを用いることである.

\section{3-5 推奨部材断面の算出}

次に, $3-2,3-3$ で算出した概算作用応力 $(1$ 次設計, 2 次設 計の概算值)を許容する柱・梁の部材断面を算出する. 算出の際の部 材断面の許容応力度の検証では, 同時に最低鉄筋量などの仕様書的 規定のチェックや, 曲げモーメント及びせん断力, 長期時, 短期時 及び保有水平耐力時, 梁であれば両端及び中央に加えて 4 分の 1 位 置での検証を行い，柱であれば，軸力を考慮して柱頭及び柱脚を検 証し，X方向及びY方向を検証するとともに，長期についてはX方 向 $\mathrm{Y}$ 方向同時作用を検証する。これは，梁・柱に求められる断面検 証の寸べて注7)を行うことであり，具体的には，第 4 章で作成した 計算シートに必要なデータを入力することで行う.

上記の断面検証は，部材断面が充分に大きければ適合するものだ が，概略審查を実現するためには，断面検証を適合させ，かつ，最 もスリムな部材断面を選出する必要がある。この報告で提示する選 出方法は, 設計実務で用いる積算手法注8) 利用して積算による施 工金額上で最も低い金額になる鉄筋本数・部材断面のものを選び出 すものである.

\section{3-6 開発例と有効性の検証}

図 4 の考え方に基づき 1 次設計の概算応力を算出するためのツ ールとして開発したものが図 7 である.このシートにスラブ厚さや 柱梁の断面寸法を入力寸ることでR C 部材の固定荷重が自動計算さ れ, スパン長や小梁方向を入力寸ることで梁の $\mathrm{C}_{0} \mathrm{Q}_{0}$ が自動計算 され, 求めようとする部位が外柱であるか内柱であるかに応じて 図 4 の計算式を用いて柱・梁に作用する応力が概算される。また, 2 次設計の概算応力を算出するシートは, 図 7 のデータを利用しな がら新たに部材種別のデータ入力をして算出するようにしている. 2 次設計の計算シート, また, 図6 6 考え方を用いて水平力分担率 を推定する計算シートは, 紙面の都合上, 掲載を省略する.

次に, これらの計算シートを利用して作用応力の概算値を算出し, 実設計と比較する. 図8 は, 鉄筋コンクリート造 3 階建て 1 階外柱 と 2 階梁の作用応力の計算例である. 図より, 1 次設計の地震時, 2 次設計について, 実設計の結果に対して概算值というレベルでは 近似した数值を出力していることがわかる. 図9 は, 図8と同じ建 物で, 耐力壁が内柱にある場合, 外柱にある場合, 隅柱にある場合 の 1 次設計及び 2 次設計の耐力壁の水平力分担率を示したものであ る. 図より, 同じ壁でも, 位置によって引き抜き抵抗力が変化し, 水平力分担率も変化することがわかる.また, 算出された概算值は, 実設計の結果の傾向をよく反映していることがわかる.

次に, 実設計の柱・梁部材と本報告による推奨部材断面とを比較 する，比較する実際の設計として, 構造設計・部材断面事例集 ${ }^{2}$ の

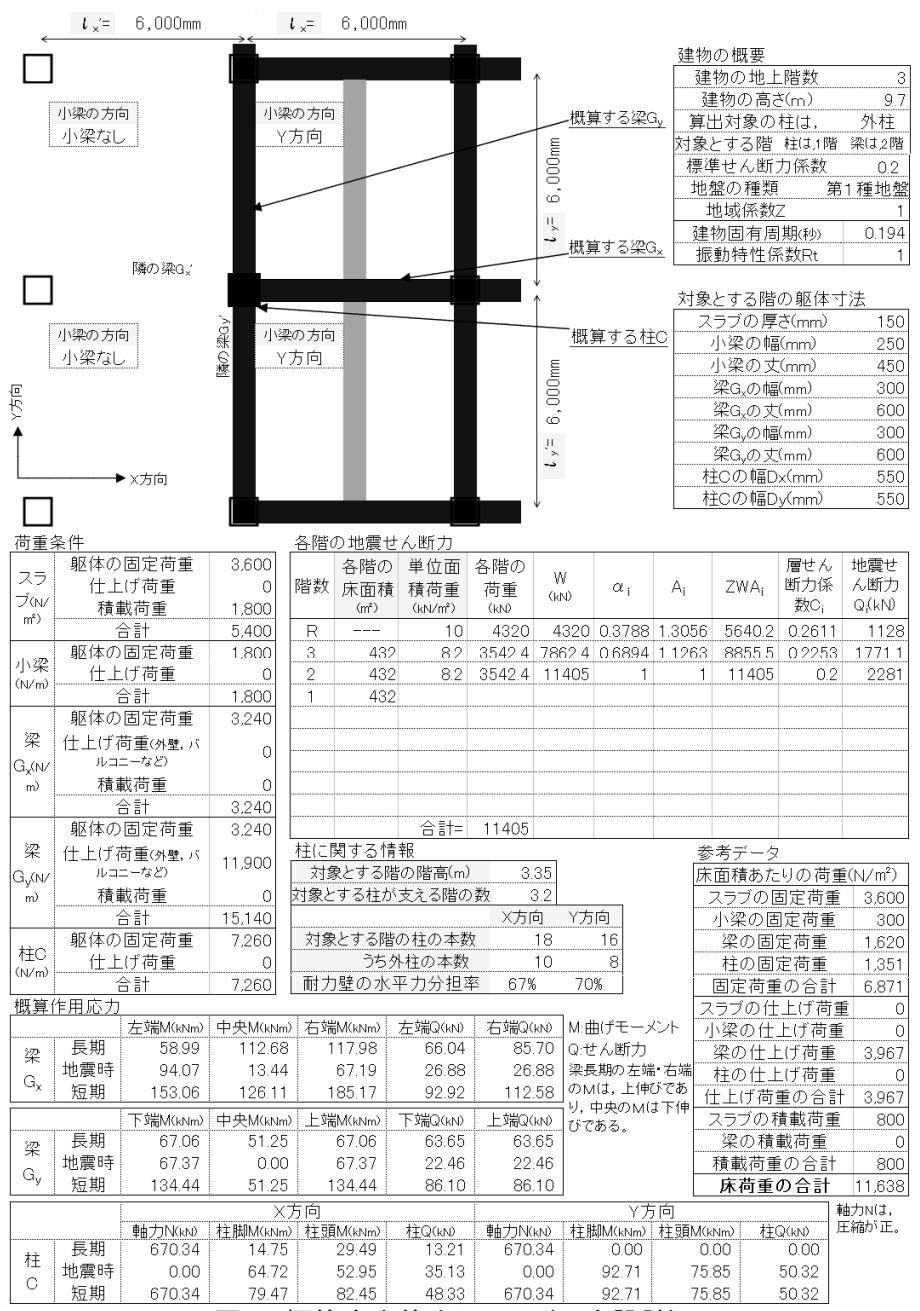

図 7 概算応力算出シート ( 1 次設計 $)$

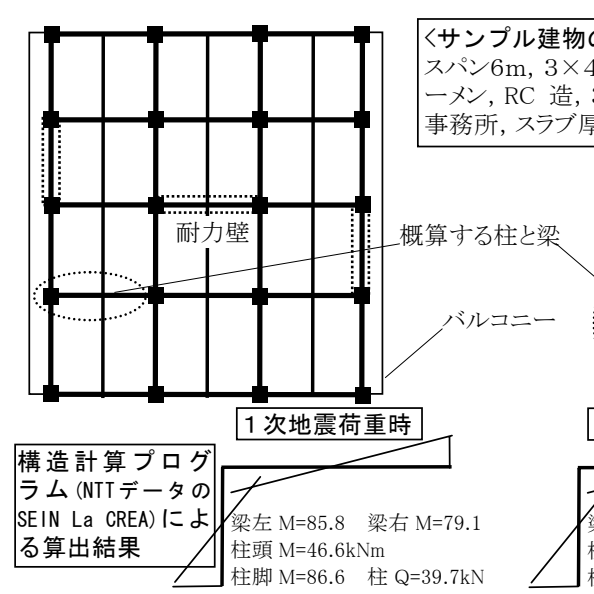

，耐力壁付きラ 一メン, RC 造, 3階建て, 積載荷重は 務所, スラブ厚 150
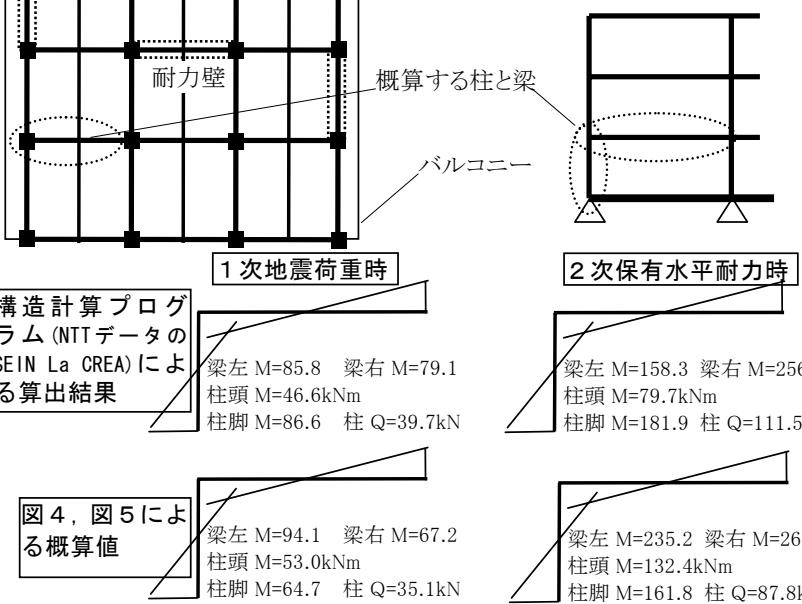

2 次保有水平耐力時

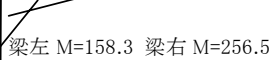
柱頭 $\mathrm{M}=79.7 \mathrm{kNm}$ 柱脚 $\mathrm{M}=181.9$ 柱 $\mathrm{Q}=111.5 \mathrm{kN}$

図 8 概算応力算出例 $(R C$ 造 3 階建て)

設計例 3-4 ( R C 造事務所 5 階建て, 而力壁付きラーメン構造) と $3-5$ (同 10 階建て) を用いる.柱・梁部材断面を算出した結果は, 表 6 のとおりである. 表より, 設計例の設計断面に対して, 概略審 査のレベルとしてはおおむね近い断面を算出していることがわかる. 


\section{4 詳細審査における審査の改善}

前報告では, 計算過程で生じる 1 ステップごとの数值のチェック に重点を置いたため, 例えば，小梁の審査では， 2 種類の $\mathrm{C}_{0} \mathrm{Q}_{0}$ 表を使って梁端などの $\mathrm{C}_{0} \mathrm{Q}_{0}$ を算出し，小梁両端のモーメント表 を使って端部などの応力を算出し， $\mathrm{T}$ 型梁の有効幅表を使って有効 幅を算出し，これらの数值を梁断面算定チェック表に入力し断面検 証していた.この方法は, 電卓で行うよりは効率的であるにしても, それぞれの表において算出された数值を手作業で入れ直すものであ った，そこで，表 2 で示した作業を 1 つ計算表で一括して行うこ とができるよう計算シートを改良した（図１０．掲載は小梁のみ). これにより, 審査者の作業内容は, 数值・文字の読取り, 判断の 3 つのみとなり，これを表 5 の作業時間に当てはめると, スラブの場 合で約1分, 小梁では約1分, 梁では約3分, 柱では約4分であった.

\section{5 結語}

本報告では，改正法が規定した厳格化審査の作業内容を分析し， 部分的にではあるが作業量と作業時間を試算した。また，概略審査 を実現するために, 企画設計段階において行われる概算応力算出手 法と積算手法を用いて推奨断面を選出する手法による審査ツールを 提示した. 詳細審査でも前報告で示した審査手法に若干の改善を加 えた。概略審査は, 改正法が規定した厳格化審査を満たさない審查 手法であるため, 詳細審査とは異なる概念ではあるが，概略審査と 詳細審查とは, 互いに長所・短所を併せ持つものであり, 連携して 用いることで審査の効率化が図られるものと考えられる，なお，概 略審查の手法は, 企画設計段階で構造部材を概算する時や, 構造設 計の冒頭で行う初期断面算出にも活用できるものと思われる.

\section{参考文献}

1 ) 北本拓也, 藤井大地 : 構造計算書審査技術に関する研究-審査技術の体系 化と㛜格化における検証-, 日本建築学会技術報告集第 14 巻第 28 号, pp. 471-476, 2008. 10

2 ) 財団法人日本建築防災協会 : 構造設計・部材断面事例集, 2007.6 3 ) 佐藤邦昭著: 現代建築学構造設計論, 鹿島出版会出版, 2000 年 11 月 10 日発行

注

注 1 ) 前報告の注 4 ) を参照.「厳格化審査」という法律用語はないが, 改正法 施行時に出された国土交通省の技術的助言に「建築確認・検査の厳格化」 という項目で解説されているので，本報告では「峳格化審査」とした。

注 2 ) 前報告の表 2 で一部を示したもの.

注 3$) 「 1 /(0.7 * 2) 」$ の数值は, 端梁の場合, 外柱と内柱に取りつくことにな るので内柱に作用するモーメントは外柱の $(1 / 0.7)$ 倍になり, 外柱では柱の モーメントを 1 本の梁で受けるのに対して内柱では 2 本の梁に配分するこ とを考慮して $(1 / 2)$ 倍になることを考慮したものである.

注 4$) 「 1 /(0.6 * 2) 」$ 数值は, 注 3$)$ の式を, 2 次設計における外柱と内柱の 配分率0.6にしたもの。

注 5 ) 改正法では, 許容応力度設計における構造解析には部材が弾性状態にあ るものとして行わなければならないことを規定した.つまり, 設計者が壁剛 性を意図的に操作して耐力壁へ作用する水平力配分を低下させることを原 則として禁止している.このため, 柱と耐力壁の剛性によって水平力が配分 されると考えられるが, 実際には,「2007年版建築物の構造関係技術基準解 説書 (国土交通省建築指導課監修)」の632ページに耐力壁の転倒モーメント による基礎の浮き上がり考慮を解説しているように, 基礎の浮き上がりに より応力再配分が生じ, 耐力壁に作用する水平力が決定される場合が多い. 注 6 ) 文献 2 ) の設計例 3-5 に保有水平耐力時の耐力壁の水平力分担率が, 下の階から順に, $0.42,0.53,0.46,0.45,0.45,0.40,0.36,0.36,0.36,0.38$,
0.13であったとされている. 1 階よりも 2 階の方が大きくなるものの上の 階ほど小さくなる傾向があり，上の階の耐力壁に作用する水平力を少なく するために，1つ下の階の分担率を $(1-\alpha)$ 倍して最上階まで繰り返すこと

で水平力分担率の高さ方向の変化を反映させるものである. $(0 . \leqq \alpha<1.0)$ 注 7 ) 保有水平耐力時の部材耐力検定を含み, 必要保有水平耐力を算出する時 に用いた部材種別FAからFDに適合する部材断面であることの検証を含む. 注 8 ) 梁・柱の施工に必要な型枠・コンクリート・鉄筋の数量を算出し, それぞれに 材料単価・施工単価を乗じて積算する。公共工事の工事費算出に用いられ る手法を準用.

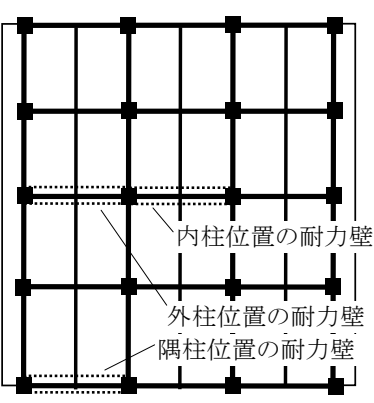

〈内柱位置の耐力壁〉 1次地震力: $62 \% \rightarrow 67 \%$ 次保有水平耐力: $47 \% \rightarrow 45 \%$

〈外柱位置の耐力壁〉

1次地震力: $46 \% \rightarrow 43 \%$ 次保有水平耐力: $38 \% \rightarrow 28 \%$

〈隅柱位置の耐力壁〉

1次地震力: $36 \% \rightarrow 29 \%$ 2次保有水平耐力: $27 \% \rightarrow 17 \%$ 数字は, 前が構造計算プログラムに よるもので, 後ろが本論文による水平 力分担率の概算值である.

建物は図8と同じ. 耐力壁を, 内柱位置, 外柱位置, 隅柱位置に配置した

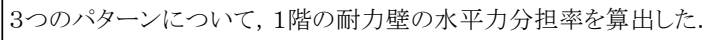

\section{図 9 水平力分担率算出例 ( R C 造 3 階建 $て)$}

\section{表 6 推奨部材断面と実設計の比較}

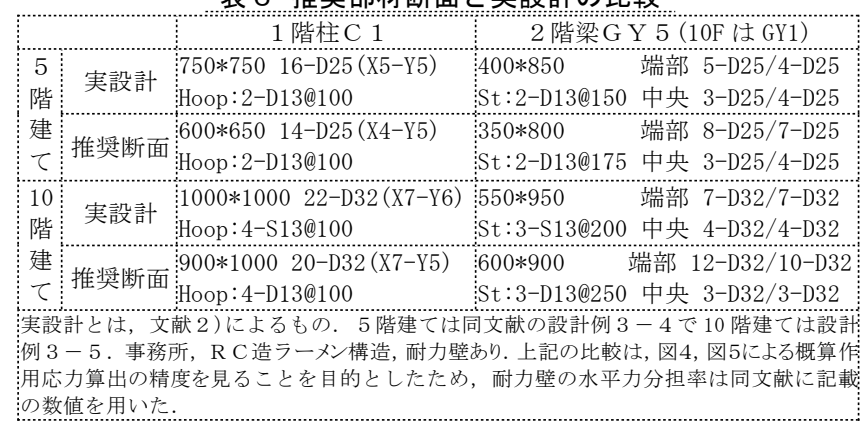
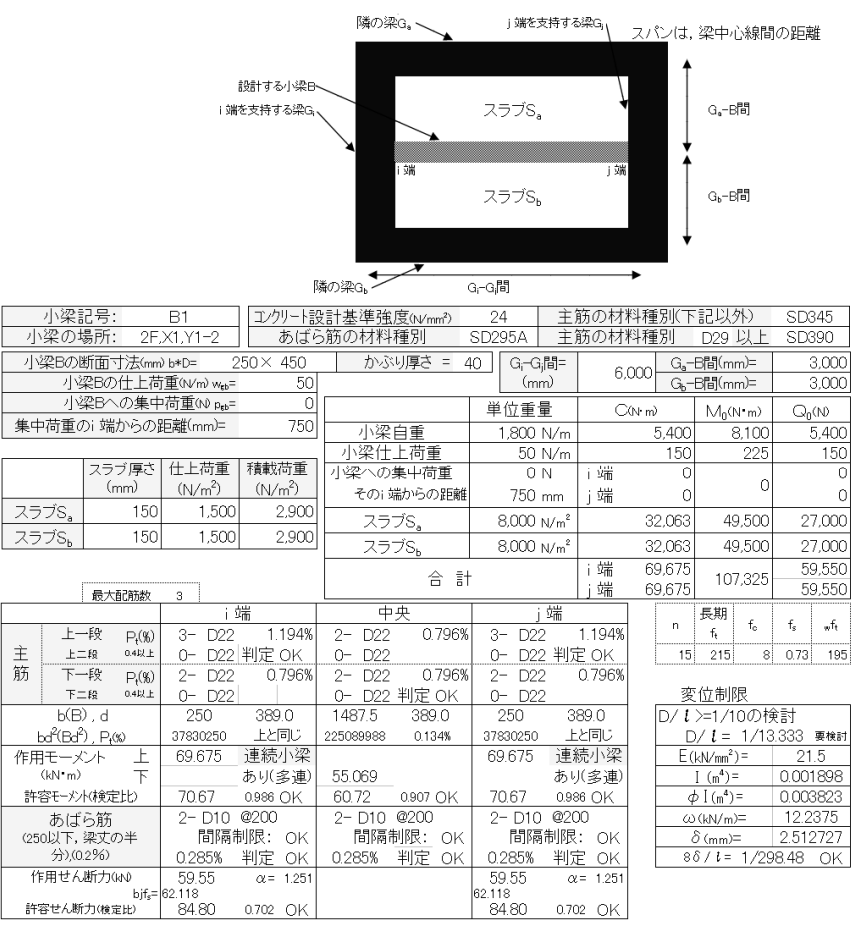

図10 改良型計算シー上-上梁)

[2010 年 2 月 19 日原稿受理 2010 年 4 月 5 日採用決定］ 